\title{
Three Birds Orchid and Crane-fly Orchid in Oklahoma
}

\author{
Dr. Lawrence Magrath \\ Corresponding Member, American Orchid Society Conservation Committee \\ Former Chair, Southwestern Region Orchid Growers Association \\ Curator, USAO (OCLA) Herbarium \\ Chickasha, OK 73018-5358
}

The Three Birds Orchid or

Nodding Pogonia, Triphora trianthophora

(Sw.) Rydb., is one of the most beautiful

jewels of the fall orchid collection in the eastern $1 / 3$ of the country. It occurs from Vermont and Ontario, south to Florida, west to Texas, and north to Michigan. Pridgeon and Urbatsch (1977) cite one collection from West Feliciana Parish in Louisiana.

In Kansas it was long listed as part of the orchid flora, based on a report by Popenoe. However, no one had seen a living specimen until Rufus Thompson, an algae specialist at the University of Kansas, discovered them in Baldwin Woods south of the City of Lawrence (Douglas County) in late August 1971. After his report several botanists from the University of Kansas also found it in Baldwin Woods and later in several other counties. Still later, when working in the herbarium at the Smithsonian Institution in Washington, D.C., I found a specimen collected by Popenoe in Topeka in Shawnee County in 1876.

In Oklahoma it has been known to occur in Cleveland County in central Oklahoma since 1947. A collection from LeFlore County in the southeastern part of the state was made in 1967. Since 1972 it has been found in Choctaw, Caddo, Adair Counties, and most recently in Canadian County by Dr. Paul Buck in 1993. There have been several other unconfirmed reports in Oklahoma. In Arkansas it has been found in several counties in the Ozark Mountains, which cross the border into Oklahoma.

One of the reasons that so few people have reported seeing this delightful little orchid is probably that it blooms in late August and early September. That is a time when few orchid or wildflower enthusiasts are out in the woods because of the ticks, mosquitoes, and miserable hot weather. Nevertheless, it is a flower well worth the trouble endured to find it. It grows in rich mixed deciduous woodlands or deciduous-pine woodlands in the deep humus or leaf mold of moist shaded areas. This species is often associated with other fall flowering orchids such as Corallorhiza odontorhiza and Tipularia discolor.

It may occur as a single stem, a few scattered stems, or as large colonies up to 3 feet in diameter with hundreds or occasionally thousands of stems, such as are found at the Battiest Site in northern McCurtain County, Oklahoma. The 7-30 $\mathrm{cm}$ (3-12 inches) plants produce from one to six (rarely seven) flowers about the size of a nickel at the tip of succulent green stems. Typically the plants are about 10$18 \mathrm{~cm}$ (4-7 inches) tall. The flowers open white with a delicate patch formed by three crests or lamellae of emerald green 
in the center of the lip. As the flowers age, they become flushed with pink or lavender. When observed under magnification the flowers appear to be sculpted out of transparent or translucent crystal. They are truly a delight to behold. The plants have underground stolons bearing fleshy tuberoids (Medley 2002). The tuberoids rarely ever penetrate into the soil, but rather appear to be confined to the layer of decaying organic matter. Any attempts to cultivate this plant should take this into account.

Oklahoma Native Plant Society (ONPS) and Southwestern Region Orchid Growers Association (SWROGA) Conservation Committees would appreciate knowing of additional locations for this orchid. It is probably more common than previously believed. However, proof is in the finding!

The Crane-fly Orchid, Tipularia discolor (Prush) Nutt., is one of the more interesting and elusive native orchids. Its name is derived from the Latin tippula "water-spider" + discolor "variegated, of different colors." It is one of the late summer orchids found in Arkansas, southeastern Oklahoma, eastern Texas, and Louisiana. The genus contains three recognized species: Tipularia josephi in the Himalayan Mountains, T. japonica in Japan and T. discolor in the United States. It ranges from Florida west to eastern Texas through Oklahoma, Arkansas, Missouri, southern Illinois, and Indiana east to Pennsylvania, New Jersey, and Massahusetts, as well as along the Atlantic Coast. It may be the most common orchid in Arkansas (Slaughter 1993). In Oklahoma it was first collected in 1968 two miles south of Honobia by Steve Stephens from the University of Kansas. The collection consisted of one flowering plant (Magrath 1973). Since then it has been found throughout the southeastern part of Oklahoma in colonies often numbering in the thousands.

According to Luer (1975) "The plants are characterized by their series of undergournd tubers which are actually corms connected by slender rhizomes." A new corm is produced each year. Each new mature corm produces a solitary ovoid, overwintering leaf which disappears in May or June. The inflorescence is produced in August. The scape is slender and is terminated by a raceme of small, dull flowers. The sepals and petals are free but one petal partially overlaps the dorsal sepal. The lip is threelobed and has a spur at the base. Homoya (1993) describes the inflorescence as "giving an impression of a swarm of flying gnats, mosquitoes, or small crane-flies."

To find a large colony of these plants in full bloom in a dimly lit woods and to watch the flowers dance with every little bit of breeze is a treat. Then they truly seem like insects in flight. Homoya (1993) notes that, "The flowers of

Tipularia are unique among North American orchids in that they are not bilaterally symmetrical. Instead, the sepals and petals are positioned so that the flower is lopsided, with an unlike number of petals and sepals to either side of the column. Moreover, the flowers are angled to one side of the main stem, some to the right, others to the left.” Homoya (1993) further notes that Tipularia commonly sets seed capsules. Occasionally, isolated solitary plants may not be pollinated, but wherever there is a population, each plant normally will have between 80 to $100 \%$ capsule set.

Tipuolaria like Aplectrum (Adamand-Eve, Putty Root) has a series of corms connected by a slender rhizome. Both produce an over-wintering single leaf, although Aplectrum is usually 2-5 times 
larger and accordion pleated, both are typically purplish on the underside of the leaf. Aplectrum is, however, a late spring to early summer flowering plant, while Tipulari is a late summer flowering plant. In Oklahoma its late flowering time overlaps with golden plume, Platanthera ciliaris, and three-bird orchid, Triphora trianthophora. Tipularia tends to grow in decaying leaf litter in relatively well drained areas often over a rocky substrate, and seems to prefer drier\#ocations than does Aplectrum. Homoya (1993) notes that Tipularia "is clearly advancing its range" in Indiana. I feel that the same is true in Oklahoma.

The orchid can be cultivated in shaded areas where decaying leaf litter that is relatively moist, but well drained. Basically the same type of habitat in which Triphora trianthophora and Malaxis unifolia (Green Adder's Mouth) would grow. I have also successfully grown it in terrarium culture. Since it produces large numbers of seed capsules, it would seem to be a good candidate for growing in flask from seed and it is to be hoped that at some time in the near future it will be available in the form of nursery propagated plants, as opposed to collected plants.

While it is hoped that this native will soon begin to come into cultivation and that the Triphora trianthophora will be found in more locations, as always, we recommend that when in natural settings leave only footprints, being careful not to damage young seedlings, and take only memories and photos.

\section{References}

Correll, D.S. 1950. Native Orchids of North American North of Mexico. Waltham, MA: Chronica Botanica Company.

Homoya, M.A. 1993. Orchids of Indiana. Indiana University Press: Indiana Academy of Science.

Luer, C.A. 1975. The Native Orchids of the United States and Canada excluding Florida. Bronx, NY: New York Botannical Garden.

Magrath, L.K. 1973. The native orchids of the prairies and plains region of North America [dissertation]. Lawrence, KS: University of Kansas.

Medley, M. 2002. Triphora in Flora of North America. Vol.26: Magnoliophyta: Liliidae: Liliales and Orchidales. Flora of North America Editoral Committee. New York and Oxford: Oxford Univ. Press.

Pridgeon, A.M. \& L.E. Urbatsch. 1977. Contributions to the flora of Louisiana. 2. Distribution and identification of Orchidaceae. Castanca 42:293-304.

Slaughter, Carl R. 1993. Wild Orchids of Arkansas. ISBN: 0-9638497-0-0.

Published by the author.

Yatskievych, G. 1999. Steyermark's Flora of Missouri, Vol 1, rev. ed. Missouri Dept. of Conservation in cooperation with the Missouri Botanical Garden Press. St. Louis, MO. 
Three Birds Orchid, Triphora trianthophora (Sw.) Rydb.

Photos courtesy Charles Lewallen.

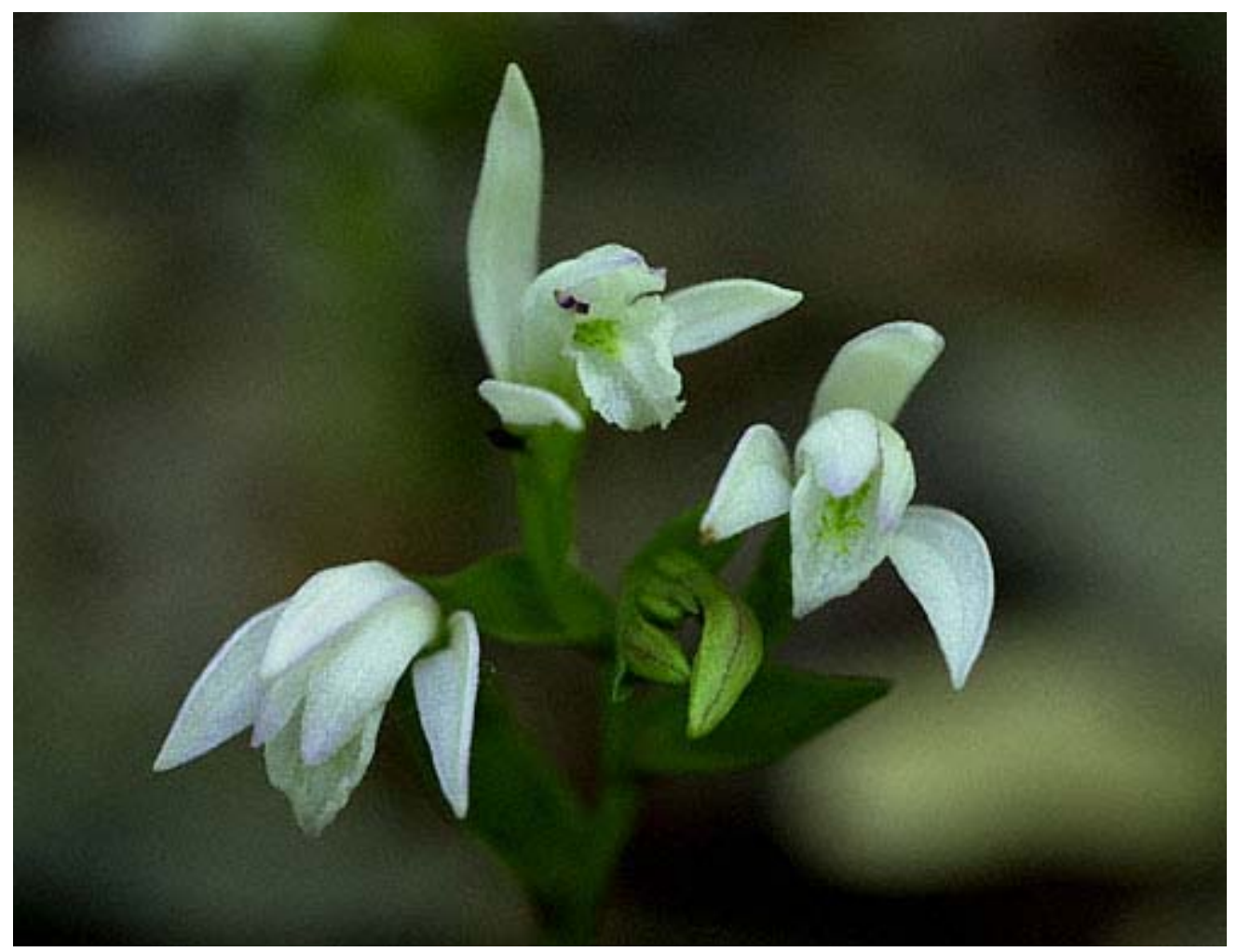

Magrath, L.K. 
Crane-Fly Orchid, Tipularia discolor (Prush) Nutt. Photos curtesy of Charles Lewallen.
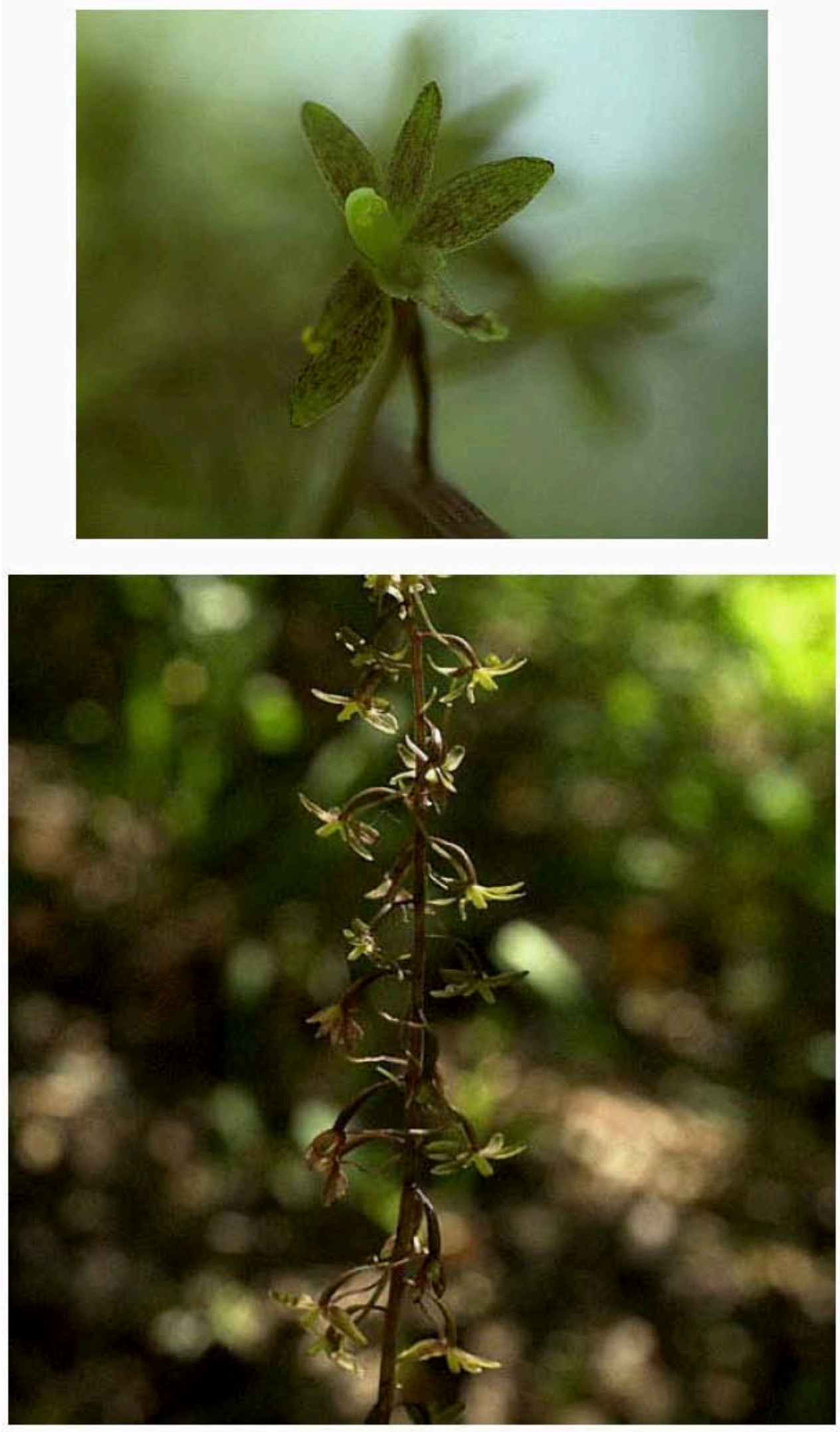

Magrath, L. K. 